\title{
Brexit, trade agreements, and CAP reform
}

\author{
Article
}

Accepted Version

Swinbank, A. (2017) Brexit, trade agreements, and CAP reform. Eurochoices, 16 (2). pp. 4-9. ISSN 1478-0917 doi: https://doi.org/10.1111/1746-692X.12156 Available at https://centaur.reading.ac.uk/72126/

It is advisable to refer to the publisher's version if you intend to cite from the work. See Guidance on citing.

Published version at: http://onlinelibrary.wiley.com/doi/10.1111/1746-692X.12156/full

To link to this article DOI: http://dx.doi.org/10.1111/1746-692X.12156

Publisher: Wiley-Blackwell

All outputs in CentAUR are protected by Intellectual Property Rights law, including copyright law. Copyright and IPR is retained by the creators or other copyright holders. Terms and conditions for use of this material are defined in the End User Agreement.

\section{www.reading.ac.uk/centaur}

\section{CentAUR}

Central Archive at the University of Reading

Reading's research outputs online 


\section{Brexit, Trade Agreements, and CAP Reform}

Alan Swinbank

The European Union's common agricultural policy (CAP) has changed considerably over the past 25 years, starting with the MacSharry reforms of 1992 which began decoupling farm support from production and facilitated completion of the Uruguay Round of GATT (General Agreement on Tariffs and Trade) negotiations in 1994. But two aspects of the old CAP persist. First, a major focus of policy remains that of supporting farm incomes. Some would argue that this is still the CAP's raison d'être, despite heightened concerns about environmental protection and enhancement, rural development, and the role a multifunctional agriculture can play (Daugbjerg \& Swinbank, 2016).

Second, despite successive 'reforms' of the CAP's domestic support provisions, import tariffs on agricultural commodities (and associated food and drink products) are essentially those that were determined by the rather modest tariff reductions achieved in the Uruguay Round. From this perspective, CAP reform is incomplete. Some of these tariffs are extremely high, often prohibitively so: on dairy products, beef, and sugar in particular. The EU's high tariffs make access to its protected market extremely difficult (see Box 1). These high tariffs also make negotiation of Free Trade Area (FTA) agreements with other countries around the world more complicated than they might otherwise be, including any FTA with the United Kingdom following the latter's imminent withdrawal from the EU ('Brexit'). 


\section{Box 1: Preferential access to protected markets}

Two basic principles of the World Trade Organisation (WTO) are: i) that its members should negotiate and then fix ('bind') the maximum tax (tariff/duty) that they are entitled to charge on imports from other WTO members - their 'bound' tariffs - and ii) that these (or any lower applied tariffs) should be levied on a most-favoured-nation (MFN) basis to all WTO members. But there are a number of ways that the EU offers preferential access to its protected market, all of which might be emulated by a post-Brexit UK.

Customs unions and free trade areas (FTAs)

WTO rules allow groups of countries to form customs unions (of which the EU is a particular exemplar) or FTAs, within which products can move freely. For FTAs this only applies to 'originating products', necessitating rules of origin ascertaining that the product was produced within the FTA by determining the minimum level of processing required. Although agreements are supposed to cover substantially all the trade between the constituent parties, agricultural products are often excluded. The Comprehensive Economic and Trade Agreement (CETA) between the EU and Canada for example will exclude poultry. The EU is a major supplier of agri-food imports into the UK, and how this dutyfree trade will be maintained, or replaced, following Brexit is as yet unknown. With regard to the FTAs the current EU has with dozens of countries around the world, the UK might hope to roll-over ('grandfather') their provisions, including continuing access for raw cane sugars for example from former ACP (African, Caribbean and Pacific) countries.

\section{Developing countries}

WTO rules allow for preferential access from developing countries, provided the importing state does not differentiate between countries at a comparable level of development. The EU's Generalised System of Preferences (GSP) offers few concessions on agri-food trade, but its Everything but Arms (EBA) scheme (available to the Least-developed Countries: LDCs) allowing duty and quota free imports is important for a number of CAP products, for example sugar. The expectation is that the UK would continue to apply EBA provisions; and for 
developing countries more generally it could choose to offer more liberal concessions on agri-food trade than the current EU's GSP.

Tariff rate quotas (TRQs)

As discussed by Revell in this issue of EuroChoices, a TRQ grants access for a specified quantity of product at a lower tariff (often zero) than the MFN tariff charged on over-quota imports. On the conclusion of the Uruguay Round the EU entered into binding commitments for current access TRQs for specified countries (e.g. butter from New Zealand) and minimum access TRQs available on a MFN basis to all WTO Members (erga omnes) to enable some penetration of its market. Subsequent negotiations following EU enlargements and resolution of trade disputes have considerably expanded the list of TRQs in the EU's WTO commitments. How these TRQs might be allocated between the EU27 and a postBrexit UK has yet to be determined.

From time-to-time the EU has unilaterally introduced TRQs on an MFN basis to resolve supply difficulties (e.g. for industrial sugar), but as these do not form part of the EU's commitments they can be withdrawn at any time. Some supposedly autonomous TRQs have nonetheless a binding nature: for example the TRQ for high-quality beef derived from cattle not treated with growth hormones introduced to resolve (at the time) the Beef Hormones dispute with the USA and Canada (Council of the European Union, 2012), discussed below. In addition, TRQs frequently form part of a FTA agreement. For example, within CETA, dutyfree imports of cheese from the EU into Canada will be limited by TRQs.

\section{Tariff reductions have not been part of CAP reform}

One outcome of the Uruguay Round was that developed countries were expected to convert trade barriers (such as the EU's variable import levies) into conventional tariffs-a process known as tariffication - which would then be reduced by 36 per cent (on average) over a transitional period, and bound. The EU broadly followed this formula, but in some instances went further. For example, the 1992 MacSharry reform reduced the support price for common wheat to $€ 119.19$ per tonne from 1995 , and yet tariffication—based on pre-1992 
price differences-would have resulted in a prohibitively high import tariff of $€ 95$ per tonne. Consequently the EU agreed it would apply a lower duty to ensure that the duty-paid import price would not exceed 155 per cent of the EU support price (Swinbank, 1997). Subsequent WTO negotiations led to revised provisions. Whilst the Uruguay Round agreement for high quality wheat, maize, and sorghum remained unchanged-resulting in duty-free imports of this group of products in recent years-it was replaced by TRQs for medium quality wheat and barley, with in-quota tariffs of €12 and €16 per tonne respectively, although both of these in-quota tariffs have on occasion been suspended. Quantities in excess of these TRQs can be imported, at what the European Commission (2014: 7) refers to as the 'dissuasive level' of the full MFN tariff (i.e. €95 per tonne for common wheat).

Other tariffs remain excessively high: a remnant of the pre-1992 CAP. Thus the MFN tariff on white sugar remains at $€ 419$ per tonne even though this is higher than the support price for white sugar (for triggering private storage aid) which currently stands at €404.4 per tonne.

The OECD's PSE (Producer Support Estimate) calculations for the period 2013-15 indicate that 19 per cent of EU farmers' gross farm receipts were dependent upon transfers from consumers and taxpayers, and suggests that 24 per cent of this took the form of market price support (OECD, 2016: 86). In the main, it is the EU's high import tariffs on agricultural products that generate this market price support.

It had been envisaged that following the Uruguay Round further negotiations in pursuit of the 'long-term objective of substantial progressive reductions in support and protection' would be pursued, and this commitment became part of the agenda for the Doha Round that began in 2001. A fairly detailed blueprint for a revised Agreement on Agriculture had been developed by 2008 (WTO, 2008) when the tariff negotiations stalled. This 2008 text envisaged that the highest tariffs could be cut by as much as 70 per cent.

Policy-makers rarely reduce tariffs unilaterally, for understandable political economy reasons. Those economic actors who stand to lose from the policy change (e.g. farmers) are likely to be better mobilised politically than 
those who gain, even though economists would argue that the latter could (and perhaps should) compensate the losers, resulting in an overall gain in economic welfare. Instead, trade negotiations usually proceed on the basis of reciprocal 'concessions' whereby, it is argued, improved access to an overseas market is achieved by conceding easier access to one's own. When the Doha Round was still in play-in 2008 for example-it was quite understandable that the EU would not unilaterally reduce its tariffs on agricultural products-even though a series of CAP reforms had made this feasible- because it planned to do so in the context of an overall package deal in which its gains in other sectors could be said to compensate its 'concessions' on agriculture. But with the Doha Round now more-or-less moribund, is this still an appropriate strategy?

\section{Free trade areas: but with whom?}

With multilateral trade negotiations stalled, attention had switched to bilateral trade liberalisation. The EU, for example, has engaged with South Korea, Japan, Canada, the USA and Mercosur (in South America), and plans to launch FTA negotiations with Australia and New Zealand. With former ACP states it has negotiated a series of Economic Partnership Agreements (EPAs) that include FTAs allowing free importation of sugar.

Nonetheless, the high tariffs on a number of CAP products have proved problematic for EU negotiators, as illustrated by the CETA negotiations mentioned in Box 1. Beef is a particularly sensitive issue for Europe's cattle farmers. These high CAP tariffs not only complicate the EU's negotiations with competitive international suppliers such as Australia and Brazil, but they are likely to complicate the UK's post-Brexit trade strategy as well.

The UK has said that it wishes to secure 'the freest and most frictionless trade possible in goods and services between the UK and the EU'; and that it 'will pursue ... a new strategic partnership with the EU, including an ambitious and comprehensive Free Trade Agreement and a new customs agreement'. At the other end of the trading spectrum it has said that 'no deal for the UK is better 
than a bad deal for the UK' (HM Government, 2017: 35 \& 65). What do these alternative scenarios imply for the UK's future agri-food trade policies?

\section{Trade with the Republic of Ireland}

'When the UK leaves the EU we aim to have as seamless and frictionless a border as possible between Northern Ireland and Ireland, so that we can continue to see the trade and everyday movements we have seen up to now' (HM Government, 2017: 21).

As the House of Lords European Union Committee (2016: 18), and others (e.g. Matthews in this issue of EuroChoices), have noted: 'the agricultural sector on the island of Ireland operates on an all-island basis', adding: 'Supply chains in particular are extremely interconnected ....' Both the Republic of Ireland and the UK have indicated that they do not wish to see the reintroduction of a hard border'-with physical checks and customs controls-following Brexit. Achieving this for trade in animals, agricultural commodities, and food and drink products, presents particular challenges. Computerised declarations for the payment of customs duties and determining conformity with rules of origin and regulatory compliance, and vehicle number-plate recognition technologies and the bar-coding of products, combined with the occasional spot-check, could probably go some way to achieving such an outcome; but the House of Lords European Union Committee (2016: 27) expressed scepticism: 'The experience at other EU borders shows that, where a customs border exists, while the burden and visibility of customs checks can be minimised, they cannot be eliminated entirely.'

An 'ambitious and comprehensive Free Trade Agreement' could be important. Provided the UK's tariff barriers remain aligned with those of the EU, and regulatory provisions are not allowed to diverge after Brexit, then fairly lax rules of origin, and minimal checks on regulatory compliance, might satisfy both parties. The EU would probably insist on this, thus foreclosing the UK's ambition to pursue 'free trade' in these products elsewhere in the world. Moreover, this 'light-touch' would have to be applied to all UK-EU27 trade, not just that between the UK and Ireland. However, if regulatory provisions are allowed to diverge, or 
the UK adopts a tariff policy that differs notably from that of EU27, then sanitary and phytosanitary (SPS) and customs controls might become inevitable.

The European Commission (2010) has outlined the rigorous border measures applied to ensure that imports of food, feed, animals and plants from third countries-which is what the UK would be-meet the EU's strict SPS requirements. For example: 'Live animals and animal products can only enter the EU through approved border inspection posts (BIPs) under strictly harmonised import conditions. These require that such imports are sourced from approved third countries, from approved or registered establishments and that the veterinary certificates accompanying the consignments must be signed by the competent authority of the exporting country providing detailed information as to the public and animal health status of the products and their conformity with the EU's import requirements' (p. 6).

The tariff issue is particularly challenging for dairy products, meats and sugar. Ireland exports beef and dairy products to the UK, but it is no longer a sugar producer and imports its requirements. Suppose the UK and EU27 do seek to conclude an ambitious and comprehensive FTA that includes agriculture, but that the UK also indicates that, post-Brexit, it would wish to pursue a more liberal import policy with regard to beef and sugar from other origins. Would EU27 be happy to accept this outcome? Irish beef producers might fear that their produce could be displaced from the British market by supplies from South America, negating in their minds the benefit of an open border. Would EU27 sugar producers be willing to accept onto the Irish market sugar refined in the UK from imported raw cane sugar, without insisting on stringent rules of origin, or even imports of sugar produced from sugar beet grown in the UK on East Anglian farms?

If an open border between the Republic of Ireland and Northern Ireland is to be maintained, without border controls on agri-food trade, then it is difficult to avoid the conclusion that:

- Regulatory convergence must be maintained post Brexit; and

- either: the UK would not be free to pursue 'free-trade' policies given that its tariff barriers on CAP products -including its other FTA 
arrangements and TRQ provisions - would have to match those of EU27;

- or: EU27 would need to quickly complete the reform of its CAP by unilaterally reducing its MFN tariff barriers to a level more compatible with the UK's trade policy aspirations towards third countries.

\section{Free (or freer) trade}

If the UK fails to conclude a comprehensive FTA with the EU27 that includes agriculture, thus enabling it to break free from the unreformed CAP's tariff barriers, what alternative agri-food trade strategies are available? The EU27 currently supplies much of the UK's imports of meats and dairy products: how easily could those supply chains be maintained?

Many analysts assume that on Brexit the UK will 'inherit' the EU's current MFN tariff bindings, and in some way share its TRQ obligations, although neither outcome is entirely certain or problem free (issues discussed more thoroughly by both Matthews and Revell in this issue of EuroChoices). The UK would not be obliged to apply its bound tariffs: it could unilaterally reduce them, provided it did so on a MFN basis. A number of economists would advocate such an approach. The UK could not, however, levy a charge on imports from Ireland lower than that applied to other WTO Members, unless trade between Ireland (i.e. EU27) and the UK was governed by a WTO compatible FTA or customs union.

Similarly, it could open TRQs larger than those it was obliged to offer as its 'share' of the EU obligation, provided it did so on a MFN basis and complied with the provisions of GATT Article XIII on the Non-discriminatory Administration of Quantitative Restrictions, but again precluding a special deal for EU27. Both options would leave the EU27 competing with suppliers from the rest of the world, UK farmers facing sharper import competition, and potentially lower prices trickling down into retail outlets. FTA agreements with Mercosur, Australia, New Zealand, etc., could significantly open up the UK's agri-food markets, placing EU27 suppliers in an uncompetitive position, particularly if the 
UK still applied its MFN bound tariffs against them. Similarly, without a UK-EU27 FTA in place, UK firms would be in competition with other third country suppliers for access to TRQs for entry into a protected EU27 market, or face the EU27's full MFN tariff.

Managing existing TRQs could prove taxing, and potentially lead to future trade disputes. For example the US has recently complained that the autonomous TRQ for hormone-free beef that the EU agreed in 2012 on a MFN basis in settlement of the Beef Hormone dispute (as mentioned in Box 1) has not proved as advantageous to US producers as had been envisaged. An increasing proportion of this TRQ has apparently been filled by non-US suppliers and consequently, it is claimed, the TRQ 'has not in practice provided benefits to the U.S. beef industry sufficient to compensate for the economic harm resulting from the EU ban' (United States Trade Representative, 2016). Accordingly the US is considering whether trade sanctions against the EU should be re-imposed. If this had happened in a post-Brexit world, from whom (EU27, UK) would the US be seeking redress?

\section{But Brexit is unlikely to result in CAP reform}

Although critical of the CAP, the UK has not been particularly successful at prompting reform. In 2005 its 15-year vision was for an industry that would, inter alia, be 'internationally competitive without reliance on subsidy or protection' (HM Treasury \& Defra, 2005: 9). Despite this rhetoric, the CAP's protective tariffs of 2017 remain essentially as negotiated in the mid-1990s. Whether a different trajectory for the CAP would have influenced the British electorate on 23 June 2016 seems doubtful. Vote Leave (2016: 13), however, had thought it relevant to comment: 'Some things we have tried to change for decades are still there, such as the Common Agricultural Policy that increases food bills and damages African agriculture.' The EU's failure to complete the reform of its CAP, leaving some excessively high import tariffs in place, is a complicating factor in designing and implementing post-Brexit trade arrangements that will not be problematic for Ireland-the EU member state most dependent on agri-food exports to the UK. As an EU member state the UK 
singularly failed to secure its Vision for a CAP without reliance on subsidy or protection; but equally it seems highly unlikely that the challenges posed by Brexit might prompt the EU to unilaterally reduce its excessively high CAP tariffs.

\section{Further Reading}

Council of the European Union (2012), The transatlantic trade dispute on "hormones" in beef comes to an end, PRESSE 171 (Luxembourg: Council of the European Union).

Daugbjerg, Carsten \& Alan Swinbank (2016), 'Three Decades of Policy Layering and Politically Sustainable Reform in the European Union's Agricultural Policy', Governance, 29(2): 265-280.

European Commission (2010), Report from the Commission to the European Parliament and the Council on the effectiveness and consistency of sanitary and phytosanitary controls on imports of food, feed, animals and plants, COM(2010)785 (Brussels: European Commission).

European Commission (2014), The EU cereals regime at http://ec.europa.eu/agriculture/sites/agriculture/files/cereals/factsheetcereals en.pdf

HM Government (2017), The United Kingdom's exit from and new partnership with the European Union, Cm 9417 (London: HMSO).

HM Treasury \& Defra (2005), A Vision for the Common Agricultural Policy (London: HMSO).

House of Lords European Union Committee (2016), Brexit: UK-Irish relations, 6th Report of Session 2016-17, HL Paper 76 (London: House of Lords).

OECD (2016), Agricultural Policy Monitoring and Evaluation 2016 (Paris: OECD Publishing).

Swinbank, Alan (1997), 'The New CAP', in Christopher Ritson and David R. Harvey (editors), The Common Agricultural Policy, 2nd Edition (Wallingford: CAB International).

Swinbank, Alan (2017), World Trade Rules and the Policy Options for British Agriculture post-Brexit, UK Trade Policy Observatory Briefing Paper 7 (Falmer: University of Sussex) at: https://www.sussex.ac.uk/webteam/gateway/file.php?name=briefing-paper7-final.pdf\&site $=18$

USTR (2016), 'Public Comments and Hearing Regarding Request To Reinstate Action Taken in Connection With the European Union's Measures Concerning Meat and Meat Products', Federal Register 28 December at: https://www.federalregister.gov/documents/2016/12/28/201631352/public-comments-and-hearing-regarding-request-to-reinstate-actiontaken-in-connection-with-the

Vote Leave (2016), Vote Leave, take control (London: Vote Leave). 
WTO (2008), Revised Draft Modalities for Agriculture, TN/AG/W/4/Rev.4

(Geneva: WTO).

Alan Swinbank, University of Reading, UK. Email: a.swinbank@reading.ac.uk

\section{Summary}

Although a number of reforms have significantly changed the Common

Agricultural Policy (CAP) over the past two decades, a defining characteristic of the policy is its prohibitively high import tariffs on a number of key commodities as tariff cuts have not formed part of CAP reform. These high tariffs, whilst protecting EU producers, complicate the EU's attempts to negotiate Free Trade Area (FTA) agreements around the world, and will likewise be problematic for agri-food trade with a post-Brexit UK, particularly over the politically sensitive border between EU27 and the UK on the island of Ireland. An open border could be more easily secured if the UK's tariff barriers on CAP products matched those of EU27. This, however, implies either that the UK will have to abandon its plans to pursue 'free-trade' policies with other countries around the world, or that EU27 needs to complete its reform of the CAP by unilaterally reducing its tariff barriers. It seems highly unlikely that the challenges posed by Brexit would prompt the EU to unilaterally reduce its excessively high CAP tariffs.

\section{Pullquote}

“The CAP's protective tariffs of 2017 remain essentially as negotiated in the mid$1990 \mathrm{~s}^{\prime \prime}$ 